\title{
A Geophysical Study of Mesquite Valley: Nevada-California Border ${ }^{1}$
}

\author{
MIT FIELD GeOPHYSICS COURSE ${ }^{2}$
}

\author{
Department of Earth and Planetary Sciences, Massachusetts Institute of Technology, Cambridge
}

\begin{abstract}
SUMMARY
This paper reports the results of a geophysical investigation of a sedimentary basin, Mesquite Valley, and its surrounding area in the Basin and Range province of the western United States. Mesquite Valley is located about $40 \mathrm{~km}$ southsouthwest of Las Vegas, Nevada, and straddles the border between Nevada and California (Figure 1). It is surrounded on three sides by mountains in which Paleozoic sedimentary rocks and Precambrian granites and gneisses crop out (Figure 1) [Burchfiel et al., 1974; Burchfiel and Davis, 1971; Hewett, 1956]. Unlike most basins in the Basin and Range province, however, there are no clearly active, range-bounding normal faults, and, in general, the surrounding topography is more subdued than in the regions farther west or north. The northwest end of Mesquite Valley is separated from a larger, essentially parallel basin, Pahrump Valley, by a saddle and small hills (Black Butte), where late Paleozoic carbonate sedimentary rocks are reported to be resting on Tertiary volcanic rocks [Hewett, 1956]. The axes of both Mesquite and Pahrump valleys are aligned along an apparently active fault, the State Line fault [e.g., Hewett, 1956]. The linearity of this fault, which is exposed in State Line pass southeast of Mesquite Valley and which is clear on aerial photos of Pahrump Valley (the Pahrump Valley fault zone of Wright et al. [1981]), may indicate a large component of strike-slip movement. Thus Mesquite Valley might owe its origin to processes more complicated than those that characterize the more typical basins of the Basin and Range province. Our principal objective was to constrain the shape of the basement topography of Mesquite Valley in order both to determine where faults might lie buried beneath the sedimentary cover and to examine Hewett's [1956] conclusion that the Paleozoic sedimentary rocks of Black Butte have been detached from the underlying pre-late Tertiary basement.

Complete Bouguer gravity anomalies at 554 sites define an elliptical low centered over Mesquite Valley (Figure 2). We compared observed profiles with those calculated assuming two-dimensional geometry representing a basin filled with
\end{abstract}

\footnotetext{
${ }^{1}$ Summary and entire article are available on microfiche. Order from the American Geophysical Union, 2000 Florida Avenue, N.W., Washington, DC 20009. Document B85-003; \$2.50. Payment must accompany order.

${ }^{2}$ Stephen Park, Isabel Brome, Paul Cunningham, Ruth Harris, Thomas Hess, John Hodges, Dwight Kirkpatrick, Theodore Madden, Michael Mellen (UCR), Jeffrey Menoher, Andrew Michael, Peter Molnar, Mark Murray, David Olgaard, Pamela Standley, Joann Stock, Christof Stork, and S. Tanner Wray.

Copyright 1985 by the American Geophysical Union.

Paper number 4B5080.

0148-0227/85/004B-5080\$02.00
}

low-density material (sediment) within a half-space of material more dense than the sediments by $0.3,0.4$, and $0.5 \mathrm{~g} / \mathrm{cm}^{3}$ (Figure 3). Calculated depths to the basement attain a maximum of at least $2 \mathrm{~km}$ and perhaps $3 \mathrm{~km}$ beneath the axis of the basin. This inferred maximum depth decreases beneath Black Butte, but a layer of light material with a thickness of a few hundred meters must nevertheless underlie it (profile E, Figure 3). Thus this result is consistent with Hewett's [1956] inference that the Paleozoic rocks exposed on Black Butte are indeed allochthonous.

A very steep gradient in the gravity field was observed on the northeast side of Mesquite Valley. This gradient could not be matched by a simple basin structure if the average difference in density between the sedimentary fill and the surrounding basement were only $0.3 \mathrm{~g} / \mathrm{cm}^{3}$. We found that to match the steep gradients with density contrasts of 0.4 and 0.5 $\mathrm{g} / \mathrm{cm}^{3}$, we were required to assume that the northeast edge of the basement in the Valley is bounded by a steep, buried escarpment (Figure 4); the dip cannot be less than $30^{\circ}$, probably is at least $45^{\circ}$ and could be vertical. The projection of this escarpment intersects the surface near the Nevada-California stateline. Therefore we presume that this escarpment was formed by slip on the State Line fault (Figure 1). The steep dip is consistent with a large component of strike-slip faulting, but clearly our data do not require this. The more gentle gradients of gravity on the other three sides of Mesquite Valley do not require steep edges of the basin, but the data cannot rule out the existence of faults bounding any or all of them.

We shot a reversed seismic refraction line, nearly $10 \mathrm{~km}$ in length, parallel to the axis of Mesquite Valley and displaced 2 $\mathrm{km}$ southwest of it (Figure 1). The travel time curves are consistent with a layered structure that includes a thin, top layer $(25 \mathrm{~m})$ with very low velocity $(1.5-1.6 \mathrm{~km} / \mathrm{s})$, which we presume to be unconsolidated sediments. A thicker layer $(\sim 0.5$ $\mathrm{km}$ ) with a velocity of about $2.45 \mathrm{~km} / \mathrm{s}$ probably represents compacted but not well-indurated sediments. A still thicker and deeper layer $(\sim 1350 \mathrm{~m})$ with a velocity of about $4.6-4.7$ $\mathrm{km} / \mathrm{s}$ probably consists of quite well indurated sediments, possibly derived from the Paleozoic carbonates in the surrounding mountains. The apparent velocity of phases refracted from the bottom layer sampled are very high (6.35 and 7.7 $\mathrm{km} / \mathrm{s}$ ), which, if we assume a planar interface, yield a much higher velocity than we would expect for the rocks exposed in the neighboring mountains. We found an acceptable match to the travel time curve, however, by assuming that the shape of the interface is concave upward and that the velocity is about $6.5 \mathrm{~km} / \mathrm{s}$. With greater concavity a lower velocity would also allow a fit. The deepest layer sampled is probably the preTertiary basement; the calculated average depth of $1.8 \pm 0.2$ $\mathrm{km}$ for it is roughly consistent with the range of depths obtained from the gravity anomalies, assuming an average density contrast of 0.4 or $0.5 \mathrm{~g} / \mathrm{cm}^{3}$.

Short electrical resistivity profiles were made using Schlum- 


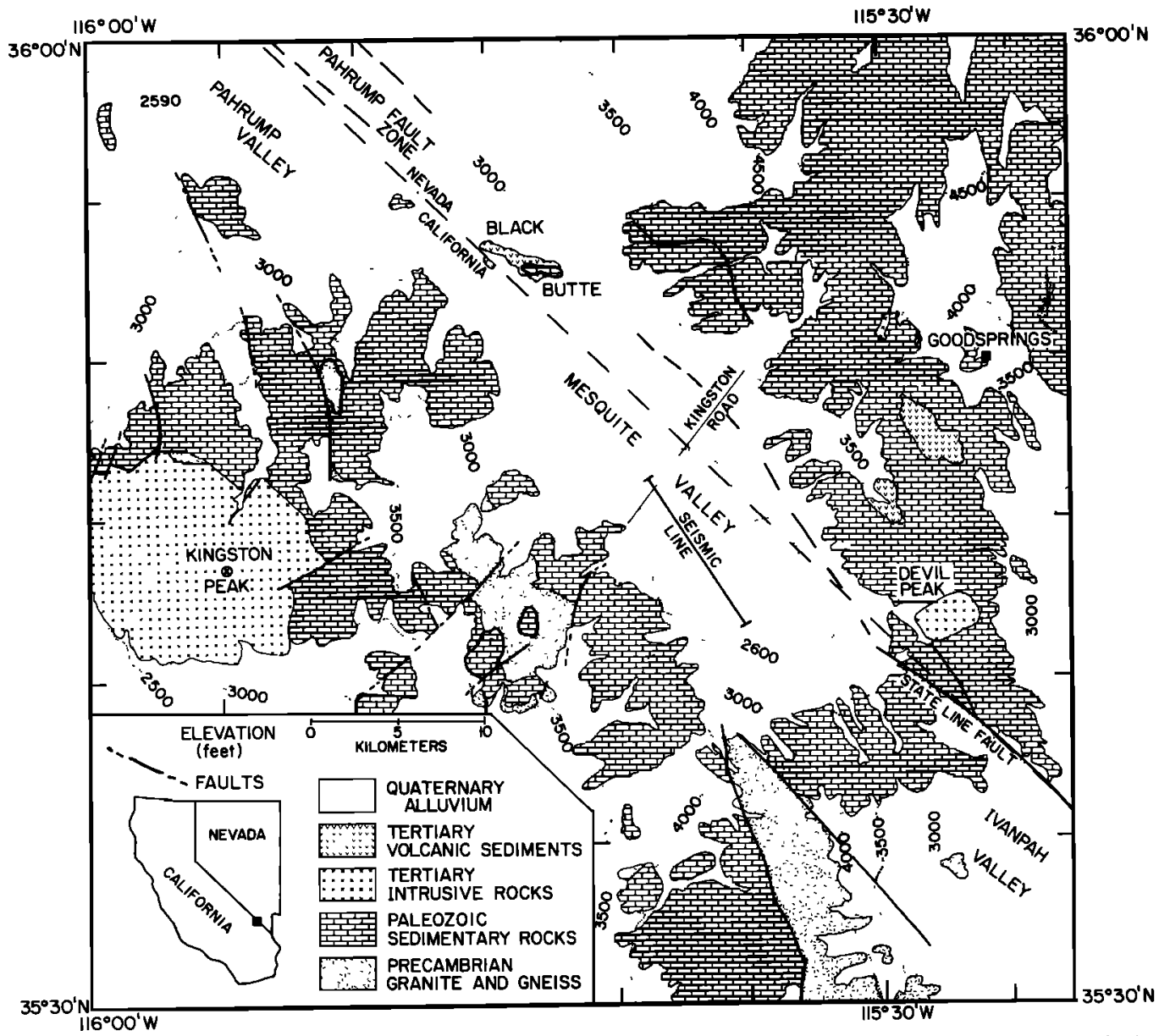

Fig. 1. Simplified geologic map of the Mesquite Valley region, showing some basic geologic units, selected faults, and elevation contours (in feet) where alluvial or lacustrine deposits crop out (modified from Hewett [1956]). Also shown are the positions of our refraction line and Kingston road along which electrical resistivity studies were made. Insert shows location of study area. 


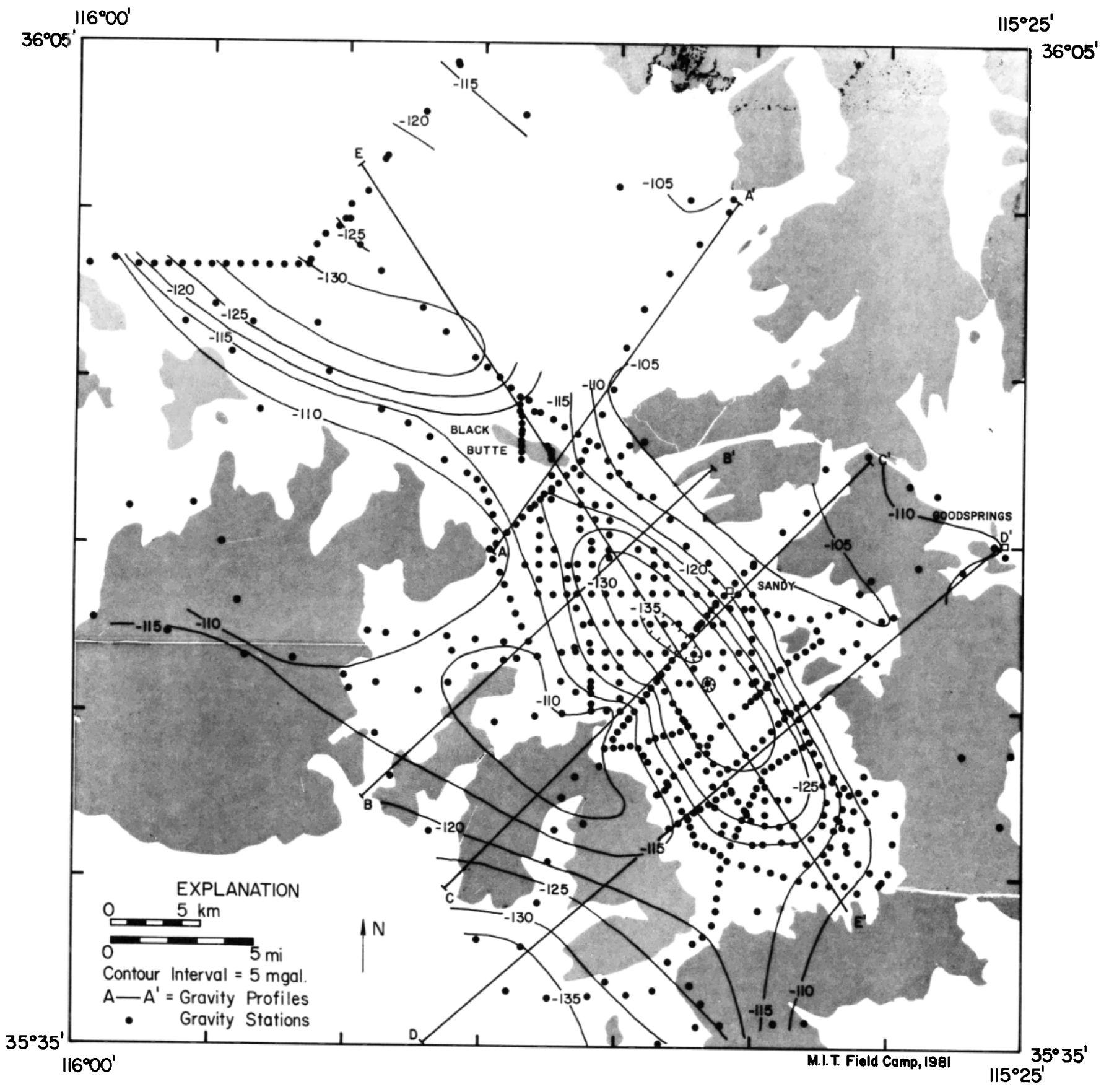

Fig. 2. Complete Bouguer gravity anomaly contour map for Mesquite Valley showing locations of protiles used for two-dimensional calculations. 

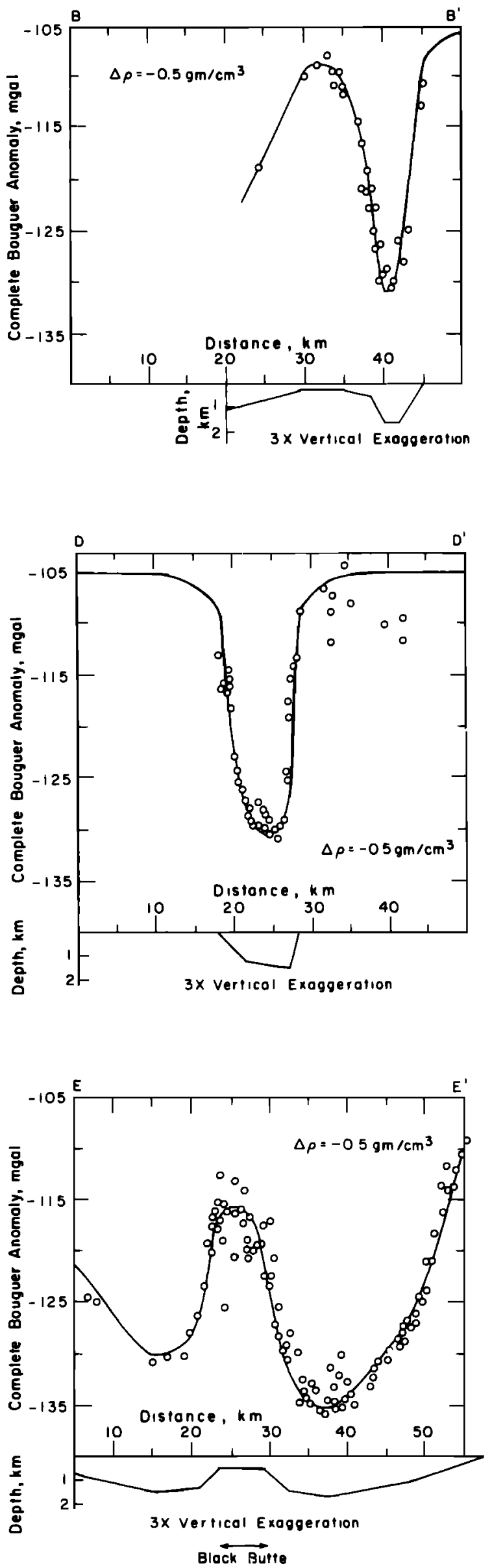
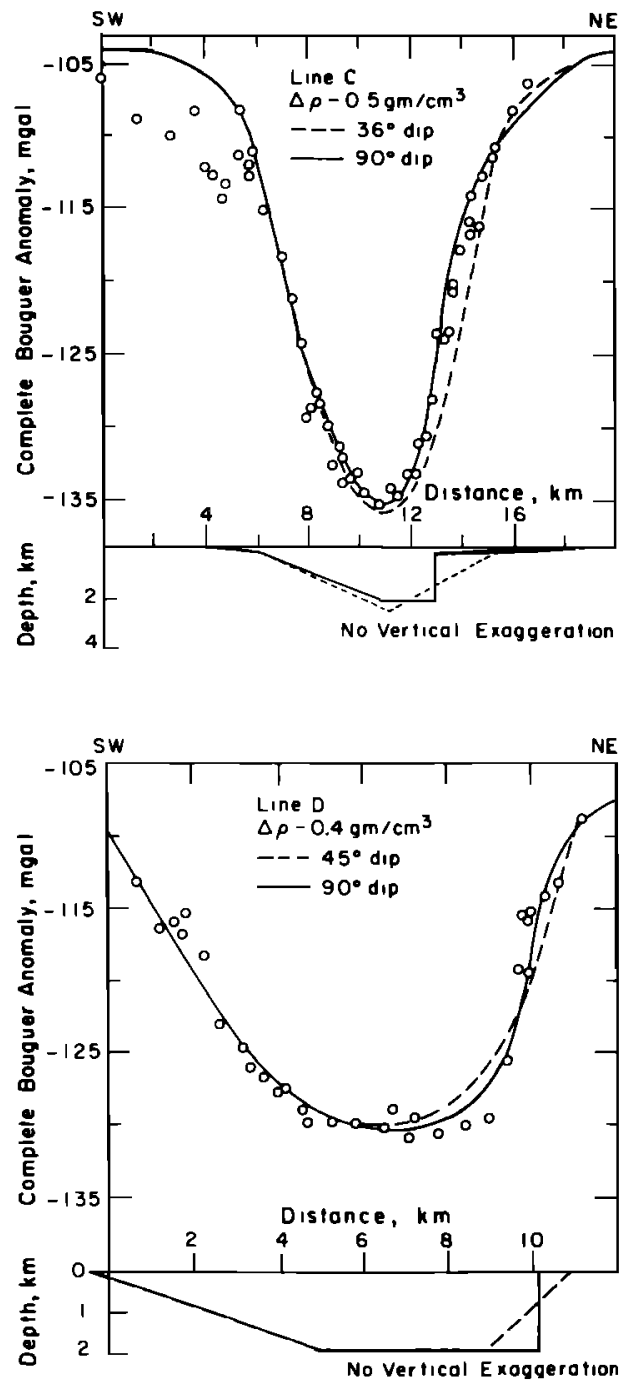

Fig. 4. Examples of good and bad fits to gravity profiles C and D (Figure 2) for average density contrasts of 0.5 and $0.4 \mathrm{~g} / \mathrm{cm}^{3}$, respectively, obtained by varying the shape of the basin. This figure illustrates that dips on the northeast side of Mesquite Valley must be greater than $30^{\circ}$ for both profiles $\mathrm{C}$ and $\mathrm{D}$.

berger and pole-dipole arrays. Using standard Schlumberger techniques [La Compagnie General de Geophysique, 1955] to analyze these measurements we inferred a layered resistivity structure. Below a thin $(50 \mathrm{~cm})$ dry zone of high resistivity $(\rho=700 \Omega \mathrm{m})$, we found a layer $80 \mathrm{~m}$ thick and of resistivity of about $30 \Omega \mathrm{m}$. This we take to be evidence of sufficient saturation that there is continuity of fresh water between the interstices of the grains. Below this layer the resistivity drops to values that are less than $0.6 \Omega \mathrm{m}$. We believe this must be due to a transition from fresh to salt water as the pore fluid. The magnetotelluric measurements suggest that this high conductivity does not extend to the depth of the basement and are consistent with the high conductivity being confined to the

Fig. 3. (opposite) Examples of good fits to gravity profiles (B, D, and $E$ in Figure 2) for a density contrast of $0.5 \mathrm{~g} / \mathrm{cm}^{3}$. The model used to generate theoretical profiles (solid lines) is shown immediately below the plot of the gravity data. Black Butte overlies the saddle in the basement of profile E. Note that the poor approximation of twodimensional geometry for profile $\mathrm{E}$ makes any inference drawn from it only qualitative. 

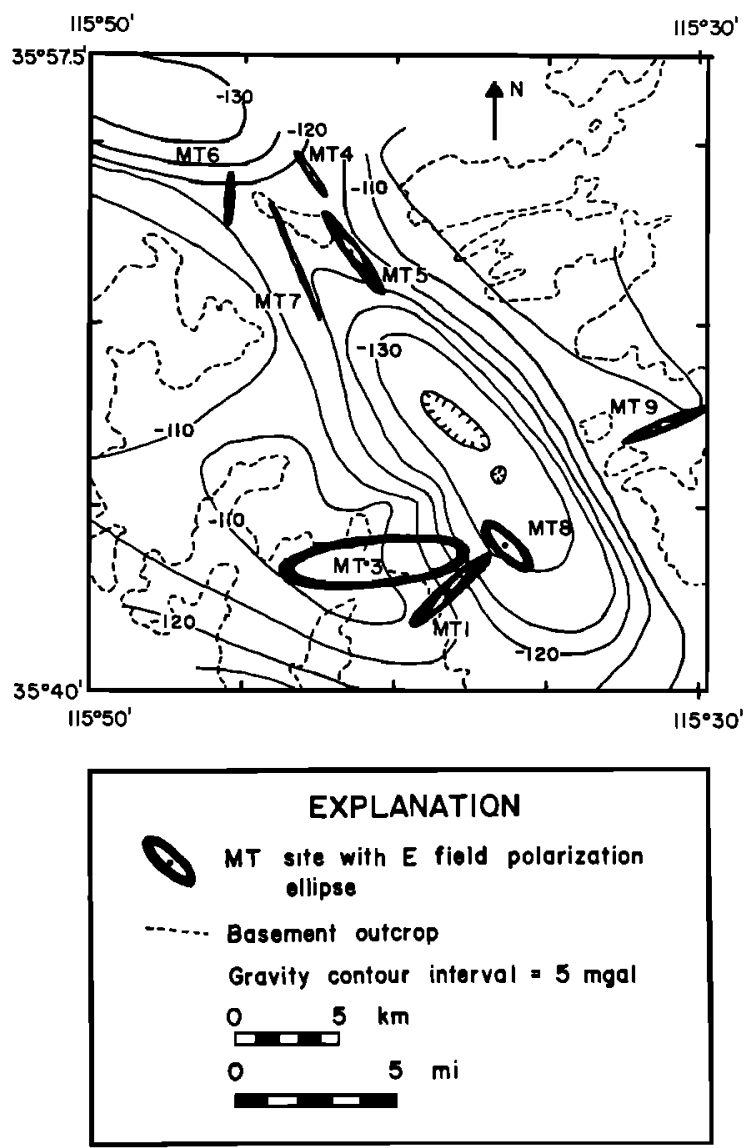

Fig. 5. Magnetotelluric results superimposed upon gravity contour map. Electric field impedance ellipses plotted at each station represent principal telluric current directions. The ellipse at site 8 is plotted at a scale 10 times larger than the others.

layer with a $P$ wave velocity of $2.45 \mathrm{~km} / \mathrm{s}$. Such a result is most easily explained by a porosity change at about $500 \mathrm{~m}$ depth, where the $P$ wave velocity increases to $4.6-4.7 \mathrm{~km} / \mathrm{s}$.

Magnetotelluric measurements were made at nine sites. At each site we measured the two horizontal components of the electric and magnetic fields, from which we determined impedance tensors. Measurements made outside the basin show that impedance ellipses, which represent the polarization of the electric field, are aligned perpendicular to the basin but that those from within the basin are aligned parallel to it (Figure 5). Current is channeled into the valley presumably because the conductivity is much higher there than in the surrounding basement rocks. Moreover, note that near Black Butte at the northwest end of the valley, the ellipses, which are aligned parallel to the telluric currents, are essentially parallel to the axis of the valley. The telluric currents do not seem to be deflected by the structure beneath Black Butte, as one might expect if the resistive basement rocks underlay Black Butte at a very shallow depth.

Thus both the gravity anomalies and the telluric currents suggest that Black Butte is an allochthonous mass, separated from the basement by hundreds of meters of low-density, lowresistivity material.
Magnetotelluric, electrical resistivity, and seismic refraction data are consistent with a top layer of increasingly consolidated sediments approximately $400-500 \mathrm{~m}$ in thickness, saturated throughout most of the thickness, with fresh water near the top and more saline water below. The higher seismic wave velocity beneath this layer implies greater induration. Both gravity anomalies and travel times from the seismic refraction profile imply a maximum depth to pre-Tertiary basement of about 2-3 km. Finally, the steep gravity gradients on the northeast side of Mesquite Valley require a steep buried escarpment, which probably marks a major fault. Given that the heights of the surrounding mountains reach about $2000 \mathrm{~m}$, the apparent vertical separation of the pre-Tertiary basement is more than $3500 \mathrm{~m}$. If this displacement occurred on one single fault or fault zone, then this fault must be comparable in significance with other range bounding normal faults in the Basin and Range [e.g., Hunt and Mabey, 1966; Pakiser and Kane, 1962]. At the same time, the apparent continuity of this escarpment with the State Line fault exposed at State Line pass and with the apparently active, northwest trending rightlateral strike-slip fault in Pahrump Valley [Wright et al., 1981] suggests that the principal component of slip on this range-bounding fault in Mesquite Valley may also be strike slip. The absence of obvious topographic expression of this fault in Mesquite Valley suggests that most of the slip probably occurred before Holocene or even late Quaternary time.

Acknowledgments. We are indebted to the University of California at Riverside and to Stanford University for providing us with seismic and gravity equipment and would like to single out Shawn Biehler and George Thompson for their roles in extending us this help, without which this study could not have been carried out. We also wish to thank Beno, Ron, and Tanya Atwater, Clark Burchfiel, Del Cate, Larky Hodges, Rick Schult, R. W. Simpson, Tom Wissler, Mary Lou Zoback, and an anonymous associate editor for help of various kinds.

\section{REFERENCES}

Burchfiel, B. C., and G. A. Davis, Clark Mountain Thrust complex in the cordillera of southeastern California: Geologic summary and field trip guide, Campus Mus. Contrib. 1, pp. 1-28, Univ. of Calif., Riverside, 1971.

Burchfiel, B. C., R. J. Fleck, D. T. Secor, R. R. Vincelette, and G. A. Davis, Geology of the Spring Mountains, Nevada, Geol. Soc. Am. Bull., 85, 1013-1022, 1974.

Hewett, D. F., Geological and mineral resources of Ivanpah Quadrangle, California, and Nevada, U.S. Geol. Surv. Prof. Pap., 275, 172 pp., 1956.

Hunt, C. B., and D. R. Mabey, Stratigraphy and structure: Death Valley California, U.S. Geol. Surv. Prof. Pap., 494-A, 162 pp., 1966.

La Compagnie Générale de Géophysique, Abaques de Sondage Électrique, Paris, 1955.

Pakiser, L. C., and M. F. Kane, Geophysical study of Cenozoic geologic structures of northern Owens Valley, California, Geophysics, $27,334-342,1962$.

Wright, L. A., B. W. Troxel, B. C. Burchfiel, R. H. Chapman, and T. C. Labotka, Geologic cross section from the Sierra Nevada to the Las Vegas Valley, eastern California to Southern Nevada, Geol. Soc. Am. Map Chart Ser., MC-28M, 1981.

MIT Field Geophysics Course, C/O Peter Molnar, Department of Earth and Planetary Sciences, Massachusetts Institute of Technology, Cambridge, MA 02139.

(Received April 18, 1984; revised April 25, 1985; accepted April 29, 1985.) 